\title{
Stanowisko grupy eksperckiej Polskiego Towarzystwa Dermatologicznego w sprawie konsensusu „Trądzik zwyczajny: patogeneza i leczenie”
}

Przegl Dermatol 2014; 101, 73

DOI: 10.5 | |4/dr.20|4.4I075

W związku z pojawieniem się na rynku farmaceutycznym preparatów generycznych limecykliny i oświadczeniem wydanym przez Urząd Rejestracji Produktów Leczniczych, Wyrobów Medycznych i Preparatów Biobójczych (URPL), praca specjalna pt. „Trądzik zwyczajny: patogeneza i leczenie. Konsensus Polskiego Towarzystwa Dermatologicznego" (Przegl Dermatol 2012; 99: 649-673) wymaga naniesienia pewnych poprawek dotyczących anybiotykoterapii doustnej w trądziku. Niniejsze sprostowanie dotyczy informacji zawartych w tabeli VII wyżej wymienionej pracy, tj. dawkowania antybiotyków doustnych w terapii trądziku zwyczajnego. Zgodnie z oświadczeniem prezesa URPL z dnia 3.10.2013 r. dotyczącym wyjaśnienia zawartości substancji czynnej produktu leczniczego Tetralysal ${ }^{\circledR}$ (lymecyclinum) i jego odpowiednika Damelium ${ }^{\circledR}$ (lymecyclinum) informujemy, że obydwa dostępne obecnie na rynku preparaty limecykliny zawierają $408 \mathrm{mg}$ substancji czynnej. W związku z tym informacja dotycząca stosowania limecykliny zawarta $\mathrm{w}$ tabeli VII powinna brzmieć: „Limecyklina 408 mg/dobę (w 1-2 dawkach) przez okres do 12 tygodni. Przy średnim nasileniu zmian trądzikowych po 10-14 dniach dawkę dobową leku można zredukować o połowę". Poprawiona tabela VII wygląda więc następująco:

Tabela VII. Dawkowanie antybiotyków doustnych w terapii trądziku zwyczajnego

Table VII. The dosage of oral antibiotics in the treatment of acne vulgaris

Limecyklina 408 mg/dobę (w I-2 dawkach) przez okres do 12 tygodni. Przy średnim nasileniu zmian trądzikowych po 10 14 dniach dawkę dobową leku można zredukować o połowę.

Doksycyklina 100-200 mg/dobę przez okres do 12 tygodni.

Tetracyklina- $\mathrm{HCl} 750-1500 \mathrm{mg}$ na dobę $\mathrm{w}$ dawkach podzielonych, co 6-8 godzin. Lek początkowo podaje się w dawkach większych, a następnie terapię kontynuuje się przez okres do 12 tygodni w dawkach stopniowo zmniejszanych.

Erytromycyna 600-1200 mg/dobę w dawkach podzielonych, co 6-8 godzin, przez okres do 12 tygodni.

\section{KOMENTARZ}

Zawarcie w pierwotnej wersji tabeli dawki $300 \mathrm{mg}$ było pewnego rodzaju niepoprawnym uproszczeniem, gdyż zgodnie $\mathrm{z}$ charakterystyką produktu leczniczego dotyczącym farmakokinetyki leku, limecyklina 408 mg podczas wchłaniania jest szybko hydrolizowana do aktywnej tetracykliny (ekwiwalentu $300 \mathrm{mg}$ ) i innych, nieaktywnych składników. Wolna tetracyklina, która jest szybko wchłaniana, przez co najmniej 12 godzin osiąga stężenia terapeutyczne w surowicy (> $1 \mu \mathrm{g} / \mathrm{ml})$. Terapeutyczne stężenia w surowicy uzyskuje się w ciągu 1 godziny, a maksymalne stężenia w surowicy (wynoszące 2-3 $\mu \mathrm{g} / \mathrm{ml}$ ) występują w ciągu 2-3 godzin od podania leku. Okres półtrwania limecykliny w surowicy wynosi około 10 godzin.

W celu uniknięcia kolejnych niejasności należy również zaznaczyć, że doustne podanie $500 \mathrm{mg}$ tetracykliny-HCl umożliwia uzyskanie porównywalnych stężeń wolnej tetracykliny w osoczu, podobnie jak w przypadku doustnego podania $408 \mathrm{mg}$ limecykliny; tj. maksymalne stężenie występuje po 1-3 godzin i wynosi $3,5 \mu \mathrm{g} / \mathrm{ml}$. Okres biologicznego półtrwania tetracykliny- $\mathrm{HCl}$ w surowicy jest jednak krótszy i wynosi 7-8 godzin.

Jacek Szepietowski', Monika Kapińska-Mrowiecka², Andrzej Kaszuba ${ }^{3}$, Andrzej Langner ${ }^{4}$, Waldemar Placek ${ }^{5}$, Hanna Wolska ${ }^{4}$, Łukasz Matusiak'

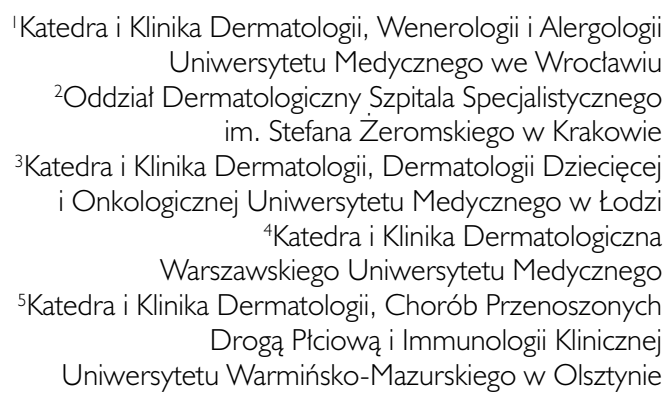
im. Stefana Żeromskiego w Krakowie ${ }^{3}$ Katedra i Klinika Dermatologii, Dermatologii Dziecięcej i Onkologicznej Uniwersytetu Medycznego w Łodzi ${ }^{4}$ Katedra i Klinika Dermatologiczna Warszawskiego Uniwersytetu Medycznego ${ }^{5}$ Katedra i Klinika Dermatologii, Chorób Przenoszonych Drogą Płciową i Immunologii Klinicznej Uniwersytetu Warmińsko-Mazurskiego w Olsztynie 